\title{
PRACTITIONERS' PERCEPTION OF VALUE IN CONSTRUCTION
}

\author{
Søren WANDAHL \\ Department of Engineering, Aarhus University Denmark, Dalgas Avenue 2, DK8000 Aarhus C, Denmark
}

Received 08 Jan 2013; accepted 12 Mar 2013

\begin{abstract}
Value delivery is basically the main purpose of construction, and in fact it is not the physical construction in itself that a client buys but the attributes or value the building provides. This value delivery is undertaken in a complex endeavour of collaboration. Throughout a building project value is in focus both implicit and explicit. Often challenges or direct problems arise during the process, which may be due to an incongruent perception of value. A survey was conducted among practitioners of the Danish building industry, aiming at investigating whether or not practitioners perceive value differently. The survey revealed that the practitioners had a diverse understanding of how to perceive value in a building project. This is problematic for the efficiency and effectiveness of building projects. Value is the underlying concept of emerging methods and concepts such as Lean Construction, Value Management and Partnering. When a homogeneous understanding of value does not exist, the full potential of applying value based concepts will not occur.
\end{abstract}

Keywords: value, survey, practitioners, efficiency, value management, value.

\section{Introduction}

Value has become a popular concept to talk about in the construction industry, almost a kind of buzz word (Kelly 2007; Male et al. 2007; Barima 2010). It is though also a fact that the whole construction industry struggles to capture, communicate and deliver value. Value is a tacit underlying concept of the whole construction process. Starting in the brief, where client's and users' values should be captured and later communicated and transformed into a design that can deliver these values to the client. In this process it is decided what value that should be delivered, hence external effectiveness is in focus. Later these values are communicated and transformed into a design concept. How well the design fulfils a client's value system determines the internal efficiency. But also the buildability of the design is of value. It influences the resources needed and thereby the productivity and internal efficiency.

In research communities value has also increased focus through e.g. among others CIB's Revaluing Construction priority theme (Winch et al. 2003; Barrett 2007). It seems that when value concepts are applied, it is often as an integrated part of other concepts, e.g. Partnering (Chan et al. 2003; Kadefors 2004; Alderman, Ivory 2007), Value Management (Green 1994; Kelly et al. 2004; Wandahl, Bejder 2006), and Lean Construction (Koskela, Ballard 2006). Since value is associated with different management concepts, it has a wide range of application. A concept with such a span can be difficult to define explicit and homogenous. The focus of this research is, therefore, on how value in construction is defined and explicitly applied, and what the implications of a limited value understanding are in the construction industry. If theory has a heterogeneous definition of value, we cannot expect practitioners to easily understand and implement managerial concepts that enhance value delivery in construction. To deliver value to our client will in future attract even more focus, due to increase awareness of cost vs. functionality. The winners will be those who understand the users' value system, and succeeds in capturing this value system and transform needs, desires, wishes, requirements, etc. into buildable designs.

The research objective is described thorough a hypothesis:

Practitioners in the building industry have vague knowledge of the value concept. Furthermore, knowledge of value in building differs between stakeholder groups.

The overall objective is to bring forward the lacking knowledge of value management and value engineering thinking in today's construction industry. Also to address the implication of such a knowledge gap in the industry. It is not within the scope of this research to outline improved value management tools that can reconfigure the industry in terms of an explicit value agenda. 


\section{Construction management and the value concept}

A conceptual understanding of value is the underlying foundation for several different management philosophies applied in construction. Since the focus of this research is on the perception of value in practice, a literature review on how value is defined and applied in different construction management contexts is undertaken to investigate if incongruent perceptions exists theoretically. Value Management and Value Engineering are selected as the theoretical framework, because they explicitly emphasises value delivery.

\section{Value management}

In general, the idea of Value Management (VM) is to increase "value for money" from the client's perspective. It is often called a value delivery method (Kelly 2007; Male et al. 2007; Fan et al. 2010). VM is applied in the early stages of a project where the problem is ill-defined, dynamic and complex (Green, Moss 1998; Thomson et al. 2003; Ellis et al. 2005; Bowen et al. 2010a; Shehu, Akintoye 2010; Vorakulpipat et al. 2010). A thriving briefing process is vital for overall project success, and many problems in the succeeding building process can often be traced back to the briefing process. VM is in that sense a promising tool for making the client's value system explicit, through among others different modes of workshop in the early project life cycle (Kelly, Male 2001; Shen et al. 2004; Fan et al. 2010; Luo et al. 2010; Abd-Karim et al. 2011; Jaapar et al. 2012). It seems that most theory on VM relies on a tacit definition of value. A few authors state that value should be seen as the level of satisfaction of the client's needs compared with the use of resources in a wide sense (Kelly, Male 2001; Shen et al. 2004; Luo et al. 2011; Abd-Karim et al. 2011). The newest understanding of VM is based on the soft system approach, which is a learning based model aiming at aligning stakeholders' value systems (Liu, Leung 2002; Shen, Chung 2002; Kelly 2007; Bowen et al. 2010a; Fan et al. 2010; Perera et al. 2011), however in practice VM is a very broad set of pragmatic management tools (Male et al. 2007; Abd-Karim et al. 2011; Jaapar et al. 2012).

\section{Value engineering}

Value Engineering (VE) is a management technique aiming at lowering cost in a construction project while remaining the technical quality and function of the product as required by the client (Al-Saleh, Taleb 2009; Zhang et al. 2009; Perera et al. 2011). VE has success when applied during detailed design, but not when applied in the early phases of a project (Green, Moss 1998; Thomson, Austin 2001). Value is defined explicitly as function divided with costs. Thereby the client's value will increased if a product is substituted with another cheaper product which holds the same function (Thomson et al.
2003; Gerhardt 2006; Perera et al. 2011). Some argues that VE and VM are synonyms (Thomson, Austin 2001; Shen, Chung 2002). This seems however to be wrong. Abd-Karim et al. (2011) and Jaapar et al. (2012) concludes that VM is a general term for different value techniques, where of VE is one of such. In general it can be concluded that VM define value as what is delivered to the client, and is conducted in a soft system approach. Opposite, VE define value as what the client pays for a delivered function, and the approach is more technical and "hard".

\section{Product and process values}

Value is not only understood differently in the different concept, but also differently within each concept. Hence a homogenous definition of value in building is missing (Barima 2010). Since a common understanding of value in building is missing, the full potential of management concepts based on value will most likely not occur. Three main value perceptions exist. A monetary approach where value is what you pay for something. A product value approach where value is associate with the quality and functional aspects of a construction in a broad sense. And a process value approach where value is perceived as moral and ethics of people cooperate to perform a given task.

On a macroeconomic level the diverse perception of value could decrease the effectiveness and efficiency of the whole building industry, with general welfare problems as consequences. A microeconomic viewpoint is in this research applied to investigate how widespread it is that participants in the building industry have a diverse understanding of the value concept.

\section{Method}

In order to accept or reject the hypothesis, data collection was necessary.

It was decided to apply a questionnaire as means of data collection. Furthermore, it was decided to use an online survey tool that could distribute the questionnaires by email and collect the data through an online database. Reported disadvantages of using questionnaire for data collection (de Vaus 1993; DelgadoHernandez, Aspinwall 2005), such as interpretation of questions, low response rate and sampling issues, were handled partly in the design of the questionnaire and partly by preliminary testing of validity and reliability.

\subsection{Questionnaire development}

The first step was to choose which variables that could support the scope of research. Table 1 illustrates how a breakdown process from nominal variable to operational question was carried out. Control over this structure was essential for making analysis possible and hence receive reliable output. 
A mixture of scales was applied, including nominal, ordinal, and interval scales. Predominant was the ordinal scale due to intensive use of the Likert scale. The first section of questions, A1 to A6, was designed to give information regarding the respondents' demographic variables. This section should group the companies according to size and type. In terms of size an interval scale asked for the number of employees, and in terms of company type a nominal scale was applied, where the respondent should choose between six predefined categories, namely contractor, client, architect, etc. Company size was based only on the number of employees, although other factors such as turnover that could be used. Furthermore, on nominal scales the respondent should answers in which geographical area the company operates and whether the company had participated in any kind of development initiatives in the building industry. Finally, section A had an open-end nominal question about the respondent's job position and an interval question regarding the respondent's experience (in years) in the building industry.

The second section, question $\mathrm{B} 1$ to $\mathrm{B} 4$, covered questions regarding variables concerning the respondent's perception of the value concept. All questions were designed as 5-point Likert scales. The Likert scale is initially perceived as ordinal because one cannot assume that respondents perceive the difference between adjacent levels as equidistant. The final section of the questionnaire, question $\mathrm{C} 1$ to $\mathrm{C} 4$, was not used in statistical analysis. It asked for volunteer contact information and gave the respondent opportunity to comment on the questionnaire in general. In total, the questionnaire contained 15 questions, which makes it possible to answer within 10 minutes.

\subsection{Data collection}

Due to the described weaknesses of applying questionnaires for data collection, strong focus was put into designing and testing prior to implementation. First the questionnaire was discussed among fellow university colleagues to ensure internal validity. Finally, the wording of the questions was worked so that the possibility of misleading and misunderstanding of questions was minimized. The original questionnaire was written in Danish language. The questions seen in Table 1 are, therefore, later translated into English language.

Pre-testing on four selected respondent were carried out. These respondents were afterwards telephone interviewed in order to bring about any misunderstandings or problems with the questionnaire. After this only small changes was needed, and the questionnaire was hence ready for distribution.

The theoretically population was all practitioners in the Danish building industry. When choosing the sample, the aim was to collect between 25-30 respondents in each of the six groups of company types, see Table 2, resulting in a total sample of approximately 150 . The sample was randomly chosen from industry databases and from yellow pages.

The survey was carried out anonymously, but respondents could provide contact details if they were interested. An email containing the cover letter, some information about the survey and a link to the webpage

Table 2. Response rate per stakeholder

\begin{tabular}{lccc}
\hline Stakeholder & Distributed & Returned & $\%$ of subset \\
\hline Contractor & 25 & 12 & $48 \%$ \\
\hline Consultants & 25 & 10 & $40 \%$ \\
\hline Architects & 30 & 10 & $40 \%$ \\
\hline Manufactures & 26 & 11 & $42 \%$ \\
\hline Authorities & 19 & 7 & $37 \%$ \\
\hline Clients & 27 & 13 & $48 \%$ \\
\hline
\end{tabular}

Table 1. Scope of questionnaire

\begin{tabular}{|c|c|c|}
\hline Conceptual factors & Variables & Operational question \\
\hline \multirow{2}{*}{ Company characteristic } & Type of company & A1: Which type of company is your company? \\
\hline & Company size & A2: How many employees are there in your company? \\
\hline \multirow{2}{*}{ Personal characteristic } & Job position & A3: What is your job position? \\
\hline & Experience & A4: How many years of experience in building do you have? \\
\hline \multirow[b]{2}{*}{ Other characteristics } & Geographical area & A5: In which regions does your company have activities? \\
\hline & Development activities & $\begin{array}{l}\text { A6: Have your company participated in development activities such } \\
\text { as e.g. partnering, lean construction, etc.? }\end{array}$ \\
\hline \multirow{2}{*}{ Product or process value } & \multirow{2}{*}{$\begin{array}{l}\text { Product and process } \\
\text { value statements }\end{array}$} & B1: In a building project value can be perceived as...? \\
\hline & & B4: The following elements are of value in a building project...? \\
\hline Value for whom & $\begin{array}{l}\text { Participants in a building } \\
\text { project }\end{array}$ & B3: Value in building is relevant for...? \\
\hline Relevance of focusing on value & Relevance & B2: In a building project it is relevant to focus on value when...? \\
\hline \multirow{2}{*}{ Comments and contact } & Comments & $\mathrm{C} 1$ : Any additional comments? \\
\hline & Contact information & Question $\mathrm{C} 2$ to $\mathrm{C} 4$. \\
\hline
\end{tabular}


containing the questionnaire were automatically distributed to the respondents. After two weeks, reminders were emailed automatically. After additional two weeks the survey webpage was closed.

\section{Results}

The analysis is carried out in two main steps (Forza 2002). Firstly, a preliminary analysis is carried out. The purpose is to validate the sample in terms of internal coherence and in terms of how well the sample mirrors the population. In this preliminary analysis the focal point is hence the demographic variables. Following the validation of the sample, hypothesis testing is applied. The methods used for hypothesis testing depends on the number of variables and the level of measurement (de Vaus 1993). In this survey mainly bivariable correlation analysis will be applied, like spearman's rho (Forza 2002).

\subsection{Preliminary analysis of validity and coherence}

The purpose of this preliminary analysis is partly to validate the sample in terms of internal coherence, to test how well it reflects the population, and partly to prepare the data for further analysis.

The respond rate can be an indication of how well the survey is designed and an indication of the relevance of the research scope. A low respond rate makes it difficult to perform valid and reliable conclusion on the data in the sample. The response rate, $R$, is by use of Eqn (1) calculated to $R=63 / 152-(9+6)=46 \%$ :

$$
R=\frac{N_{\text {returned }}}{N_{\text {sample-(ineligble }+ \text { unreac hable })}} \cdot 100 \% .
$$

Table 2 illustrates the proportion of response by stakeholder. The response rate of each subset is almost evenly distributed. Authorities are the subset with the lowest response rate. This might be due to the fact that authorities are indirectly involved in most construction projects.

Different surveys within the construction industry have typically a response rates between $20 \%$ and $55 \%$ (Albert et al. 2003; Haynes, Love 2004; Bröchner et al. 2005). The response rate in this survey at $46 \%$ is acceptable and above average for socio-technical research in general (Futrell 1994). Therefore, the following will only analyse the composition of the sample independent of the response rate.

There are three main groups of demographic variables, company characteristic, personal characteristic, and other characteristic. It is important that the sample reflects the population.

The distribution of company types differs: Clients (22\%), Main contractors (19\%), Architects (16\%), Consultants (14\%), Manufactures (10\%), Authorities (8\%), and Sub contractors $(6 \%)$. The aim was a distribution of around $12 \%$ each. The distribution is roughly considered evenly distributed. The years of experience from the respondents illustrates that $80 \%$ of the sample has more than 10 years of experience. The respondents could hence be considered as very familiar with the building industry, which validates the data. On the other hand, this distribution of experience does not fully represent the population. The distribution of geographical activity area is evenly distributed. The company size is considered evenly distributed with a range from 0-10 employees (19\%), 11-50 employees (38\%), 51-200 employees $(41 \%)$, and $>200$ employees $(39 \%)$.

The sample can be validated by analysing the internal coherence. The questionnaire is design in such a manner that some questions are related to the same nominal variable. Question B1 and B4 is both related to product value and process value. It is, therefore, possible to analyses if product value and process value respectively is perceived and answered coherently by respondents. Spearman's rho test is applied for this purpose:

$$
r_{s}=1-\frac{6 \sum d^{2}}{n\left(n^{2}-1\right)} .
$$

In Tables 3 and 4 the relation between different product variables and process variables are illustrated respectively. It can be concluded that the respondents perceive questions concerning product value and process value respectively coherent. Among others, this increases the validity of the questionnaire design, and hence the results from the later analysis. In Table 5 the basic data of the variables is illustrated.

Table 3. Spearman's rho correlation between variables

\begin{tabular}{|c|c|c|c|c|c|}
\hline & B1.4 & B4.1 & B4.3 & B4.5 & B4.7 \\
\hline B1.4 & & & & & \\
\hline B4.1 & .115 & & & & \\
\hline B4.3 & $.411 * *$ & $.651 * *$ & & & \\
\hline B4.5 & $.260 *$ & $.439 * *$ & $.326^{* *}$ & & \\
\hline B4.7 & $.427 * *$ & $.331 * *$ & $.362 * *$ & $.409 * *$ & \\
\hline
\end{tabular}
associated with product value

Table 4. Spearman's rho correlation between variables

\begin{tabular}{|c|c|c|c|c|c|}
\hline & B1.3 & B4.2 & B4.4 & B4.6 & B4.8 \\
\hline B1.3 & & & & & \\
\hline B4.2 & $.513 * *$ & & & & \\
\hline B4.4 & $.338 * *$ & $.562 * *$ & & & \\
\hline B4.6 & .196 & $.271^{*}$ & $.307^{*}$ & & \\
\hline B4.8 & .060 & .295 & $.335^{* *}$ & $.531 * *$ & \\
\hline
\end{tabular}
associated with process value 
Table 5. Initial analysis of the variables concerning the perception of value

\begin{tabular}{|c|c|c|c|c|}
\hline B1: Different product and process value statements & $\mathrm{n}$ & Mean & Variance & SD \\
\hline Value is price of a building project & 63 & 2.79 & 1.13 & 1.06 \\
\hline Value is how the client perceives the final building & 63 & 4.24 & 0.44 & 0.67 \\
\hline Value is how well the cooperation is & 63 & 3.59 & 0.79 & 0.89 \\
\hline Value is the quality of the construction & 63 & 4.24 & 0.80 & 0.89 \\
\hline \multicolumn{5}{|l|}{ B4: The following elements have value in building... } \\
\hline The total price & 63 & 4.03 & 0.52 & 0.72 \\
\hline Cooperation on site & 63 & 4.03 & 0.74 & 0.86 \\
\hline Project duration & 63 & 3.89 & 0.94 & 0.97 \\
\hline Project management control & 63 & 4.25 & 0.64 & 0.80 \\
\hline Architecture & 63 & 4.27 & 0.43 & 0.65 \\
\hline Interpersonal knowledge & 63 & 3.78 & 0.76 & 0.87 \\
\hline The technical execution & 63 & 4.25 & 0.48 & 0.69 \\
\hline Repeating partners & 63 & 3.95 & 0.92 & 0.96 \\
\hline \multicolumn{5}{|l|}{ B3: The relevance of value for different trades } \\
\hline Main contractors & 63 & 4.08 & 0.78 & 0.89 \\
\hline Contractor & 63 & 3.97 & 0.81 & 0.9 \\
\hline Consultants & 63 & 4.19 & 0.51 & 0.72 \\
\hline Architects & 63 & 4.27 & 0.59 & 0.77 \\
\hline Manufactures & 63 & 3.6 & 0.92 & 0.96 \\
\hline Authorities & 63 & 3.54 & 1.22 & 1.1 \\
\hline Clients & 63 & 4.6 & 0.31 & 0.55 \\
\hline \multicolumn{5}{|l|}{ B2: The relevance of value in building project in general } \\
\hline The relevance of value in building project in general & 63 & 4.44 & 0.57 & 0.76 \\
\hline
\end{tabular}

In general the sample is considered valid, and it represents the population well. Thus the data in the sample is valid and further analysis of the data is possible.

\subsection{Hypothesis testing of practitioners perception of value}

In general the respondents find it relevant to focus on value in building projects. Furthermore, the mean score to the question " $B 2$ : In a building project it is relevant to focus on value" is $4.44 \pm 0.76$, and $92 \%$ of the respondents answered either 4 or 5 on a 5 -point Likert scale. It can hence be concluded that it is important to focus on value in a building project. However, when looking at the question "B3: Value in building is relevant for..." the average mode of all answers is 4 , but the mode for the client is 5 . It is, therefore, further analysed whether value is equal relevant for all participants in building projects.

In general the respondents perceive value as most relevant for the client; the mean score is $4.60 \pm 0.55$. Moreover, value is not very relevant for the authorities, mean score of $3.54 \pm 1.10$. The score is however above 3 in all groups, which illustrates that value in general is perceived as an important topic. The relevance of value for different types of companies differs with 30\%. It can also be concluded that the practitioners with most influence on the design solution (clients, architects, and consultants) is those where value is most relevant. This reveals that value is perceive as closely related to design and usability and less related to the actual building process where the structure is erected. This observation can be confirmed by a statistical test. It is investigated if the client score (maximum) is different from the score of authorities (minimum). Since both scales are ordinal Spearman's rank correlation coefficient should be used. The $\mathrm{H}_{0}$ hypothesis is that the two scores are related. Spearman's rho is calculated by Eqn (2), and shows that correlation between B3.6 (authorities) and B3.7 (client) is $r_{s}=-0.010(\alpha=0.939)$. Spearman's rho is very close to 0 which means that the two variables are not correlated. The zero hypotheses can be rejected, which in practical terms means that when client receives a high score from a respondent the authorities do not.

It is relevant to investigate relations between experience and perception of value. Since experience is measured on an interval scale Pearson's correlation, r, is applied:

$$
r=\frac{\sum X Y-\frac{\left(\sum X\right)\left(\sum Y\right)}{n}}{\sqrt{\left(\sum X^{2}-\frac{\left(\sum X\right)^{2}}{n}\right)\left(\sum Y^{2}-\frac{\left(\sum Y\right)^{2}}{n}\right)}} .
$$


The hypothesis is that a more experienced practitioner has acknowledged the importance of focusing on process values (average of question B1.3, B4.4, B4.4, B4.6 and $\mathrm{B} 5.8)$, in construction projects. The correlation is $r=0.075(\alpha=0.28)$, which is a non-significant relationship. A parallel relationship test of experience in relation to question $\mathrm{B} 2$ "In a building project it is relevant to focus on value" gives $r=-0.058(\alpha=0.32)$. It can, therefore, be concluded that experience has no influence on how a construction practitioner perceives value.

When talking to practitioners of the building industry it is sometime observed that some tends to think that value is related to price. Theoretically, it is acknowledge that value often is measured in a price relation. To test this, question B1 asks "In a building project value equals price". When looking at the answers to this question there seems to be a diverse perception. The mean score is $2.79 \pm 1.06$, which illustrates that there is a tendency to reject the relation, but the standard deviation is high. It would hence be relevant to view the answers in relation to the respondents' company type.

From Table 6 it is seen that the mean score in the perception of value equals prices differs $35 \%$. It seems that the closer one is to the actual erection of the building the more one agrees that value equals price. Contractors and manufactures have a mean score above 3.1 whereas the client and architect have a mean score below 2.5, and, therefore, do not equal price to value. The client and the architect view value as a broader concept than price. Price is what one pays for value they believe.

Wandahl (2004) documented that the different participants in a construction project had different value focus. One way of discovering difference in the answers is to look for variance in perception of product value vs. process values. Section B4 in the questionnaire is designed for this purpose. When respondents were asked which elements that have value in a building project, product value (price, quality, time, design and performance) scores highest with an average of 4.15 compared to process values (cooperation, management, knowledge, etc.) which scores 3.92 in average. An analysis of average score per trade in relation to product and process values is shown in Figure 1.

Table 6. Mean score and Standard Deviation of "B1.1: value equals the price of the building" for the different types of companies

\begin{tabular}{ll}
\hline Type of company & Mean \pm SD \\
\hline Contractor & $3.5 \pm 1.08$ \\
\hline Manufacture & $3.3 \pm 1.00$ \\
\hline Main contractor & $3.1 \pm 1.00$ \\
\hline Authority & $3.0 \pm 1.26$ \\
\hline Consultant & $2.7 \pm 0.82$ \\
\hline Client & $2.5 \pm 1.00$ \\
\hline Architect & $2.4 \pm 1.02$ \\
\hline
\end{tabular}

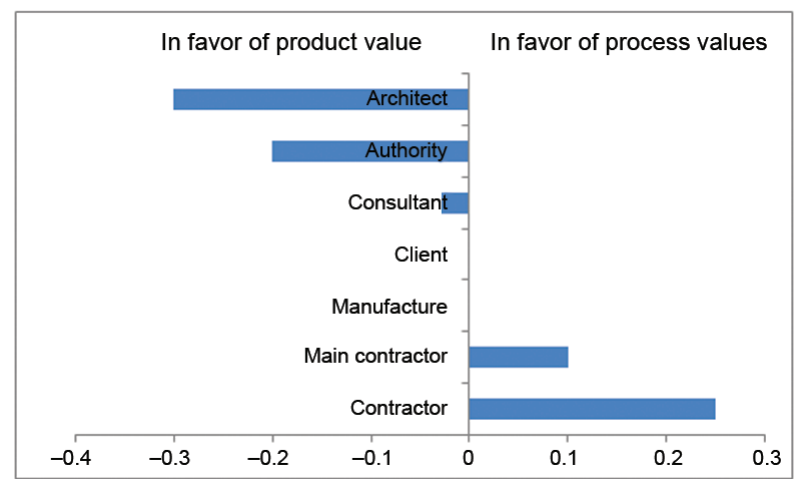

Fig. 1. Difference in average score of product and process values shown per stakeholder

Figure 1 shows the difference in average scores between process values and product values. Architects have in average rated product value 0.3 higher than process values. Clients and manufacturer has in average rated product value exactly equal to process values. Finally, contractors have in average rated process values 0.25 higher than product value. The longer distance one has to the actual production onsite the more one is interested in the physical product and its attributes. On the other hand, the one performing the real value-adding work is more in flavour of a smooth process.

This finding substantiates the challenge of phase transition between design and construction, which indicates that the design team is less receptive towards buildability and the efficiency of the actual construction process. This is no surprise as design and value creation in relation to the product and its attributes is their main task. Contrary it can potentially reduce the effectiveness of the production process.

\section{Discussion of implication}

Derived from the above mentioned findings, implications for practice are discussed here.

The understanding of value seems to follow the industry structure, which is known for is fragmentation. It is often pointed out that construction is a serial process with limited overlap between phases. Recently research shown that inter-phase periods are a time when value for the project easily can decrease. Several reasons for this exists, among others contractual agreements, change in persons, etc. In a popular term this problem is often called "over the wall syndrome" (Kamara et al. 2001). In other words the construction industry is sub optimizing each phase due to legal arrangement and thereby oversees the unexploited opportunity for added value arising from a holistic lifecycle view on the construction process. The possibility of exceed costs from corrections due to lack of communication of product requirements (the client's value system) is visible.

Other industries, such as the automobile industry, have long ago discovered the necessity of capturing 
and communicating the customers' value system. Kano et al. (1984) presented a study conducted by Toyota that presented a way to deal with customer product requirements. Kano discovered three different types of requirements, which is quite analog to the above mentioned value loose in phase transition, unexploited opportunity for added value, and exceeds costs. Kano defined these three different categories of requirements as a) one-dimensional, which is directly expressed in the client's brief; b) Must-be, which is tacit but expected by the client, and object to great disappointment if not fulfilled; c) Attractive, which often also is unspoken, and can create high satisfaction if fulfilled. Kano concluded that all three categories is equal important but differently worked.

All groups of stakeholders in the survey found it important to focus actively on value during a construction project. There were though significant differences in the perception and use of value methodologies. From an implementation and change viewpoint it is positive that there seems to be no need for developing a sense of urgency - it is already there. In respect to Kotter's 8 steps to successful change, this step 1 is the only one dominantly present. Kotter's second step is to form a powerful coalition. This is a task for the client. Therefore, to move the industry further on, clients need to act as change agents. Of course this is not possible for non-professional and one/few time clients. In these cases the building owner consultant needs to step in. This view is supported by the findings stating that value is most important for the client, and therefore the one to drive the change. Only in few countries and in few engineering programs an actual client education exists.

Based on the research findings, the following is recommended as future steps toward a more integrated value delivery methodology in construction:

- Improving inter-phase knowledge exchange. Winch et al. (1998) introduced the concept of 'project performance gap' which focuses on the delivery team's ability to fulfill the clients requirements. Atkin et al. (2003) and Wandahl (2012) elaborates on this performance gap and argues that it is related to the fragmented and sequential construction process. Needed is knowledge exchange in terms of nonoperational information, which could be taken care of by improving tendering material, process workshops as part of the tendering process, and increased project work-through.

- Improving the clients brief to be even more value orientated. This involves more value workshops and user involvement. Current state-of-the art research on value management outlines several methods for improving the clients brief. These should be adapted by the building industry.

- Improving the clients' knowledge towards being "professional clients". National initiatives aiming at educating clients towards being more "professional" should be initiated.

- Incorporate value delivery in tendering selection criteria. When using Most Economically Advantageous Tender, the client should outline criteria for value management expertise.

A road ahead is to develop a more tool or "how to" based approach to value delivery. The conclusion is that if the client does not ask for a better collaborative value delivery approach, the design team and the construction team does not offer it. In the long term a difficult task will be to anchor the change, or in other words to institutionalize value management in the construction industry as a whole.

\section{Conclusions}

This study explored how construction practitioners perceive and apply value in construction. In general terms value delivery is the overall aim of construction, but the study reveals that value delivery often is an unspoken and overseen discipline lacking formal acknowledgement of methods. The variation in what is perceived as value is broad which makes it difficult aligning on the client's value system. A questionnaire sample of 63 respondents evenly distributed across different stakeholder groups founds the data in this research.

Research results show that all practitioners in general are focused on delivering value. The overall average score on a 5-point Likert scale is 4.44. Client stands out as the stakeholder for which value focus is most important, with an average score of 4.6. In the other end authorities is the stakeholder with lowest importance of value focus, with an average score of 3.54 .

Price focus is highest among contractors, and lowest among architects with a score of 3.4 and 2.4 respectively.

The study revealed that there is significant difference among the stakeholders in relation to product focus (price, quality, time, etc.) or process focus (cooperation, management, knowledge, etc.). The product focus is prominent among architects and consultants, and opposite contractors is more focus on process values. The client has in average a balanced viewpoint of focus on product values and process values.

The research objective was put forward as a hypothesis, stating that practitioners have vague knowledge of the value concept, and that this knowledge differs between the different stakeholder groups in construction. The hypothesis can based on the results only partly be verified. It cannot significantly be verified that practitioners in the building industry have vague knowledge of the value concept, but it is neither prominent. Different possible agendas for increasing the general knowledge of value in building is proposed, among others increased awareness of phase transition issues and benefits of a more educated and "professional" client. 


\section{References}

Abd-Karim, S. B.; Lowe, D. J.; Abdul-Rahman, H.; Wang, C.; Yahya, I. A.; Shen, G. Q. 2011. Integrating risk and value management using IRVM workshops: case studies in infrastructure projects in UK, Scientific Research and Essays 6(12): 2470-2479. http://dx.doi.org/10.5897/SRE10.1088

Albert, P. C. C.; Daniel, W. M. C.; Kathy, S. K. H. 2003. An emperical study of the benefits of construction partnering in Hong Kong, Construction Management and Economics 21(5): 523-533. http://dx.doi.org/10.1080/0144619032000056162

Alderman, N.; Ivory, C. 2007. Partnering in major contracts: Paradox and metaphor, International Journal of Project Management 25(4): 386-393. http://dx.doi.org/10.1016/j.ijproman.2007.01.002

Al-Saleh, Y. M.; Taleb, H. M. 2009. The integration of sustainability within value management practices: a study of experienced value managers in the GCC countries, Project Management Journal 41(2): 50-59. http://dx.doi.org/10.1002/pmj.20147

Atkin, B.; Borgbrant, J.; Josephson, P. 2003. Construction process improvement. $1^{\text {st }}$ ed. New York: Taylor \& Francis. $320 \mathrm{p}$.

Barima, O. K. B. 2010. Examination of the best, analogous, competing terms to describe value in construction projects, International Journal of Project Management 28(3): 195200. http://dx.doi.org/10.1016/j.ijproman.2009.05.009

Barrett, P. 2007. Revaluing construction. Oxford: WileyBlackwell. $296 \mathrm{p}$

Bowen, P.; Edwards, P.; Cattell, K.; Jay, I. 2010a. The awareness and practice of value management by South African consulting engineers: preliminary research survey findings, International Journal of Project Management 28(3): 285295. http://dx.doi.org/10.1016/j.ijproman.2009.07.001

Bowen, P.; Jay, I.; Cattell, K.; Edwards, P. 2010b. Value management awareness and practice by South African architects: an empirical study, Construction Innovation 10(2): 203-222. http://dx.doi.org/10.1108/14714171011037192

Bröchner, J.; Josephson, P.; Alte, J. 2005. Identifying management research priorities, Construction Management and Economics 23(8): 793-796. http://dx.doi.org/10.1080/01446190500249569

Chan, A. P. C.; Chan, D. W. M.; Ho, K. S. K. 2003. Partnering in construction: critical study of problems for implementation, Journal of Management in Engineering 19(3): 126-135. http://dx.doi.org/10.1061/(ASCE)0742597X(2003)19:3(126)

De Vaus, D. A. 1993. Surveys in social research. Melbourne: Allen \& Unwin Pty Ltd. 379 p.

Delgado-Hernandez, D. J.; Aspinwall, E. M. 2005. Improvement tools in the UK construction industry, Construction Management and Economics 23(9): 965-977. http://dx.doi.org/10.1080/01446190500204705

Ellis, R. C. T.; Wood, G. D.; Keel, D. A. 2005. Value management practices of leading UK cost consultants, Construction Management and Economics 23(5): 483-493. http://dx.doi.org/10.1080/01446190500040711

Fan, S. C.; Shen, Q. P.; Luo, X. C. 2010. Group decision support systems in value management, Construction Management and Economics 28(8): 827-838. http://dx.doi.org/10.1080/01446191003758171

Forza, C. 2002. Survey research in operations management: a process-based perspective, International Journal of Operations \& Production Management 22(2): 152-194. http://dx.doi.org/10.1108/01443570210414310

Futrell, D. 1994. Ten reasons why surveys fail, Quality Progress 27(4): 65-69.
Gerhardt, D. J. 2006. Managing value engineering in new product development, Value World 29(2): 26-32.

Green, S. D. 1994. Beyond value engineering: SMART value management for building projects, International Journal of Project Management 12(1): 49-56. http://dx.doi.org/10.1016/0263-7863(94)90009-4

Green, S. D.; Moss, G. W. 1998. Value management and postoccupancy evaluation:closing the loop, Facilities 16(1): 34-39. http://dx.doi.org/10.1080/014461999371538

Haynes, N.; Love, P. 2004. Psychological adjustments and coping among construction projects managers, Construction Management and Economics 22(2): 129-140. http://dx.doi.org/10.1080/0144619042000201330

Jaapar, A.; Zawawi, M.; Bari, N. A. A.; Ahmad, N. 2012. Value management in the Malaysian construction industry: addressing a theory and practice gap, Procedia - Social and Behavioral Sciences 35(1): 757-763. http://dx.doi.org/10.1016/j.sbspro.2012.02.146

Kadefors, A. 2004. Trust in project relationships - inside the black box, International Journal of Project Management 22(3): 175-182. http://dx.doi.org/10.1016/S0263-7863(03)00031-0

Kamara, J.; Anumba, C.; Evbuomwan, N. 2001. Assessing the suitability of current briefing practices in construction within a concurrent engineering framework, International Journal of Project Management 19(6): 337-351. http://dx.doi.org/10.1016/S0263-7863(00)00015-6

Kano, N.; Seraku, N.; Takahashi, F.; Tsuji, S.-I. 1984. Attractive quality and must-be quality, The Journal of the Japanese Society for Quality Control 14(2): 39-48.

Kelly, J.; Male, S. 2001. A value management approach to aligning the team to the client's value system. Glasgow: COBRA.

Kelly, J.; Male, S.; Drummond, G. 2004. Value management of construction projects. Oxford: Blackwell Publishing. 367 p.

Kelly, J. 2007. Making client values explicit in value management workshops, Construction Management and Economics 25(4): 435-442. http://dx.doi.org/10.1080/01446190601071839

Koskela, L.; Ballard, G. 2006. Should project management be based on theories of economic or production?, Building Research \& Information 34(2): 154-163. http://dx.doi.org/10.1080/09613210500491480

Liu, A. M. M.; Leung, M. 2002. Developing a soft value management model, International Journal of Project Management 20(5): 341-349.

http://dx.doi.org/10.1016/S0263-7863(01)00023-0

Luo, X.; Shen, Q. P.; Fan, S. C. 2010. A case-based reasoning system for using functional performance specification in the briefing of building projects, Automation in Construction 19(6): 725-733. http://dx.doi.org/10.1016/j.autcon.2010.02.017

Luo, X.; Shen, G. Q.; Fan, S.; Xue, X. 2011. A group decision support system for implementing value management methodology in construction briefing, International Journal of Project Management 29(8): 1003-1017. http://dx.doi.org/10.1016/j.ijproman.2010.11.003

Male, S.; Kelly, J.; Gronqvist, M.; Graham, D. 2007. Managing value as a management style for projects, International Journal of Project Management 25(2): 107-114. http://dx.doi.org/10.1016/j.ijproman.2006.09.001

Perera, S.; Hayles, C. S.; Kerlin, S. 2011. An analysis of value management in practice: the case of Northern Ireland's construction industry, Journal of Financial Management of Property and Construction 16(2): 94-110. http://dx.doi.org/10.1108/13664381111153097

Shehu, Z.; Akintoye, A. 2010. Major challenges to the successful implementation and practice of programme 
management in the construction environment: a critical analysis, International Journal of Project Management 28(1): 26-39.

http://dx.doi.org/10.1016/j.ijproman.2009.02.004

Shen, Q.; Chung, J. 2002. A group decision support system for value management studies in the construction industry, International Journal of Project Management 20(3): 247-252. http://dx.doi.org/10.1016/S0263-7863(01)00076-X

Shen, Q.; Li, H.; Chung, J.; Hui, P. 2004. A framework for identification and presentation of the client requirements in the briefing process, Construction Management and Economics 22(2): 213-221.

http://dx.doi.org/10.1080/0144619042000201411

Thomson, D. S.; Austin, S. A. 2001. Construction value management revisited: the designer's role. Glasgow: COBRA, 334-345.

Thomson, D. S.; Austin, S. A.; Devine-Wright, H.; Mills, G. R. 2003. Managing value and quality in design, Building Research \& Information 31(5): 334-345. http://dx.doi.org/10.1080/0961321032000087981

Vorakulpipat, C.; Rezgui, Y.; Hopfe, C. J. 2010. Value creating construction virtual teams: a case study in the construction sector, Automation in Construction 19(2): 142-147. http://dx.doi.org/10.1016/j.autcon.2009.11.016
Wandahl, S. 2004. Visual value clarification - a method for an effective brief, Journal of Civil Engineering and Management 10(4): 317-326. http://dx.doi.org/10.1080/13923730.2004.9636325

Wandahl, S.; Bejder, E. 2006. Value management in the briefing process, The Value Manager 12(2): 3-10.

Wandahl, S. 2012. Phase transition - break down the walls, in Proceedings of CIB conference on Management of Construction, 26-29 June 2012, Montreal, Canada, 776-786.

Winch, G.; Courtney, R.; Allen, S. 2003. Re-valuing construction, Building Research \& Information 31(2): 82-84. http://dx.doi.org/10.1080/09613210301996

Winch, G.; Usmani, A.; Edkins, A. 1998. Towards total project quality: a gap analysis approach, Construction Management and Economics 16(2): 193-207. http://dx.doi.org/10.1080/014461998372484

Zhang, X.; Mao, X.; Abourizk, S. M. 2009. Developing a knowledge management system for improved value engineering practices in the construction industry, Automation in Construction 18(6): 777-789.

http://dx.doi.org/10.1016/j.autcon.2009.03.004

Søren WANDAHL. Docent (Professor), PhD, MSc.ENG and Manager of the construction management research group at Department of Engineering at Aarhus University in Denmark. Board Member of Lean Construction DK and Chairman of the Danish association of teachers in construction management. Research interest is optimization of construction processes, among others in relation to lean construction, concurrent engineering and energy efficient construction management. 